\title{
Notes on the bagual:
}

\section{cattle raising, hunting and conservation in the Brazilian Pantanal}

\author{
Felipe Süssekind \\ Department of Social Sciences, Pontifícia Universidade Católica do Rio de Janeiro, \\ Rio de Janeiro/RJ, Brazil.
}

\section{Summary}

Pantaneiro ${ }^{2}$ cattle have many facets. Firstly, they are the object or the product of the main economic activity of the region; secondly, they are a key element in the ecological dynamics of the flood plains of the Pantanal; and finally, they are the subject of unique cultural practices and experiences. The articulation of these three modes of existence is discussed in this article, based on an ethnography carried out on farms in the southern Pantanal region. The proposal is to reflect on the Pantanal concept of bagual and the way it relates to the dichotomies of tame and feral, traditional and modern.

Keywords: ethnoecology; multispecies; Pantanal; animal husbandry; bagual.

\section{Notas sobre o bagual:}

\section{pecuária, caça e conservação no Pantanal brasileiro}

\section{Resumo}

O gado pantaneiro é múltiplo. Em primeiro lugar, ele é o objeto ou o produto da principal atividade econômica regional; em segundo, é um elemento chave na dinâmica ecológica das planícies inundáveis do Pantanal; e é, por fim, tema de uma série de práticas e experiências culturais singulares. A articulação entre esses três modos de existência é discutida neste artigo a partir de uma etnografia realizada em fazendas situadas na região sul do Pantanal. A proposta é refletir sobre o conceito pantaneiro do bagual em suas articulações com as dicotomias entre o manso e o bravo e entre o tradicional e o moderno.

Palavras-chave: etnoecologia; multiespécies; Pantanal; pecuária; bagual.

\footnotetext{
1 Bagual is the term used in the Pantanal for wild or feral cattle. Some authors prefer the spelling "baguá", closer to its pronunciation, but I chose "bagual" because it's the consolidated spelling in Portuguese.

2 "Pantaneiro" is the term that designates the inhabitants of Pantanal, both human and nonhuman.
} 


\title{
Notes on the bagual:
}

\section{cattle raising, hunting and conservation in the Brazilian Pantanal}

\author{
Felipe Süssekind
}

I

My father told us that long ago, my great-grandmother was caught with a rope. She had been staying on the bagual cattle lot. And the guys were on the lookout to catch her. A person in these circumstances becomes totally wild, right? Changed. She got lost and for almost a year it was like this, everybody looking for her. One day they left early and saw some cattle standing in a forest capão $0^{3}$. Cattle uses certain birds a lot: the curicaca and the anhuma, warn the cattle. As they sing, the cattle turn around like this... And the guys need a really good horse, to catch them. They say she was sitting down, breaking nuts in the feeding trough. It was she. By the feeding trough, near the cattle. The cattle didn't even... It was my great-grandmother! She had become wild, totally bagual.

The capão was like from here to there. Then the guys took off. But they say she ran hard, you know? The horse had to sweat to catch up with her. Only this one guy caught up, almost in the forest. He threw his rope around her, pulled it tight. But she resisted all she could... Then they threw another rope, everybody came and they caught her. They looked after her, brought her to church and everything and she came back to normal. But they say that after a month she passed away.

Altino, one of Santo Antônio ${ }^{4}$ Farm's cowboys, narrated the case to me in June 2008. The farm, located in the municipality of Corumbá, was the headquarters of a scientific project investigating the behavior of jaguars, and one of the bases of my fieldwork ${ }^{5}$. The narrative refers to the time when the great-grandmother of the narrator was still young. She "runs hard" and then she is "caught with a rope" like a heifer. Altino had been raised on another farm, the Bodoquena, one of the largest and best-known properties in southern Pantanal, where he had contact with bagual cattle. This kind of cattle, according to him, liked 'capões' with denser vegetation, such as the "aguaçuzâ". "Bagual" is currently very rare and possibly extinct in the wetlands of the rivers Miranda and Abobral, the area where the Santo Antonio Farm is located, but its presence persists in the cowboys' memory. In conversations and interviews for my research, bagual was defined as "loose", "unbranded" and "no man's" cattle that "lives in the bush".

The only direct reference to an animal that fits this category, in my field notes, was a photograph that belonged to the foreman of Santo Antônio Farm, Seu Joaquim. We were talking in the cafeteria, and Seu Joaquim had brought a small photo album to show me. In one of the images, he posed with a jaguar that had been captured for the research project. "Small" - he laughed - "but it came out well in the picture". Then, another picture of Seu Joaquim with the jaguar, one of him butchering a cow, then riding a buffalo and finally some images of cowboys working the cattle. In one of them, there is a skinny well-grown calf tied up in the back of a tractor. He explained that the animal had got lost in an invernada (pasture area) and had "turned bagual".

\footnotetext{
3 Capão is a patch of arboreal vegetation growing in non-floodable areas of the Pantanal, forming forest islands distributed through the plains. 4 In this article I chose to use fictitious names for the farm and my interlocutors.

5 The research was carried out on cattle farms hosting Conservation Biology studies on jaguars (Panthera onca). My proposal was to investigate the relationship between scientific field practices and the knowledge practices of cowboys and residents of Pantanal farms (Süssekind 2010, 2012, 2014).
} 
During the time I spent on the farm, I tried to learn more about handling practices and the routine of cowboys by closely following their work with cattle. Seu Joaquim and the other cowboys were excited that I was photographing and filming and that I would ultimately show my work in Rio de Janeiro. On November 1 2008, Riquelme, the farm's truck driver, invited me to bring salt and vitamins for the bulls with him. He was responsible for feeding and had been insisting for days on showing me how tame they were. Chico, who was in charge of the trough salt, followed along. First we went to the barn where the bags of feed were stored and on the way back walked by the corral, where three sheep were tied in the back of a truck. The farm was getting rid of the goat house and some animals had been offered to the residents, as Riquelme explained while driving back to the retiro ${ }^{6}$.

After handing over the sheep to the foreman, we headed for the pasture where the bulls were. Once there, he called my attention to the quiet behavior of the animals and made some recommendations, which included not making sudden movements and not staring at them. After we got off the truck, Riquelme and Chico started taking the bags of feed off the back and dumping the contents in the trough. Gradually, the animals started gathering around us. The size of the bulls was impressive, and Riquelme made a point of showing me that it was possible to walk amongst them, because they were so tame. He would translate the various marks on their hide: the mark of Santo Antônio Farm, another from a neighboring farm, the year of birth... These marks overlapped on a first layer of skin, the hide of the animal. The bulls were all Nelore Zebu, the "white cattle" prevalent throughout the Pantanal region. On the way back to the retiro, Riquelme correlated livestock tameness to a contrast between the present and the past:

Now it's all changed; the farmer used to say: on my farm the horses are 'chucros', only a good cowboy can ride them! Today the farmer says that even children can ride his troop and that the cattle are tame. Today the guy who says he has bagual cattle and chucros on his farm is outdated.

He said that the farmers used to brag about killing jaguars, that they "were proud to go after them", while nowadays (in a clear reference to the farm owner, who was funding a research project on his property) they "actually wanted jaguars on their property". I asked him what the neighboring farmers thought about preserving the jaguars, and he said:

Not everyone... Only a few people accept the idea. Next door, at the neighboring farm, knowing about the project and all, the guy already said that if the jaguar eats his cows, he'll kill it. They don't care if there's a collar or not. Many see it as a predator that brings losses. Many still think like that: It killed my cattle; I'll kill it.

The radio collar is mentioned here as a kind of property mark, but not recognized as legitimate by the farmer who said he was going to kill the jaguars. Riquelme continued with his reasoning:

What does the farmer want to do? He wants to clear the pasture. Clear the field and create a pasture area for the cattle. All farmers. Even I, if I had a farm, I would do this. But then he does not think, I cleared up the area, I removed the capybara, I removed the white-lipped peccary, I removed the collared peccary, I removed the marsh deer - in the case of the Pantanal, right? - And I will bring the white cattle.

The argument evokes the availability of food for the jaguar given the transformation of the environment and the elimination of native species:

The food it used to eat became scarce; it's no longer there. So what happens? What it used to eat is gone... So it starts eating the white cattle, which the guy brought there. I think for the jaguar nothing changed, there's still food available, so it's not going anywhere.

6 Retiro is a housing and cattle management unit outside the farm headquarters. 
I want to draw attention at this point to the contrast between the white cattle - cattle "the guy brought there," in the words of Riquelme - and bagual cattle, which is mentioned in passing with the broncos. Chucro and bagual are terms that designate feral animals or, in a sense, wild. They appear in this quote as indices of the past, of something left behind, while the white cattle (tame) marks a transition to the present. In addition to "white", the farm cowboys used a number of different terms for both the colors of the cattle and the horses: "brasina" (red and black like embers), "dapple" and "bay", among other terms. Just like the bulls, the farm's beef cattle were predominantly white (or "smoke", with grey spots), with the other colors restricted to dairy cattle or working cattle. The color of cattle has important references in anthropological literature ${ }^{7}$ and here, together with the shape of the body and of the horns, it also plays a fundamental role in the identification of each animal by the cowboys,

During my time on the Santo Antônio Farm, I talked about cattle mostly with the foreman, Seu Joaquim. When I arrived at the farm for the first time, he and the farm herd showed me a list of animals, divided into categories. The term "tambeiro" refers to tame cattle, including the "dairy cows" and the "sinuelos", animals that, as he told me at the time, "even have a name". "Sinuelos" (like Judas cows) are oxen that guide the herd with the cowboys and are used to gather the cattle dispersed in a field. The five thousand head of cattle on the farm were classified as "calved cow", "bull", "heifer", "calf", and by their age, gender, and function. The term bagual did not appear on his list, but Seu Joaquim (who took pride in the strict and controlled management of the Santo Antônio Farm) made a point of saying that he had experience with bagual and "with all kinds of cattle, after working for thirty-two years on the Bodoquena Farm" (the same farm where cowboy Altino had worked).

Bodoquena was a very traditional farm in the region, with over four hundred thousand hectares when it was established on the former Francesa Farm ${ }^{8}$ estate. To talk about his experience with the bagual, Seu Joaquim narrated an event to me that happened in the early 1970 - the partial sale of the property to the "owner of the LS brand," Mr. Laucídio Coelho, one of the most influential farmers in southern Pananal at the time. According to Joaquim's testimony, there was a large herd of bagual cattle in an area where the Bodoquena "still had a lot of wildwood". As the new owner had no interest in these cattle, the farm cowboys had to catch them, "one by one, with the rope". The episode was particularly interesting to me, because the result of this negotiation was the San Francisco Farm, which combined cattle raising with ecotourism and hosted a jaguar conservation project.

Seu Joaquim was a cowboy when he took part in the "bagualhação" of that herd, and said that at the time over two thousand head of cattle roamed freely on the property sold and were then captured. He described how the cowboys had brought these cattle with the help of Judas cows to be incorporated gradually to the farm herd. Then the bagual herd was added gradually to the tame cattle so that they would get used to eating salt off the feeding troughs and losing their fear of humans, until they were tamed.

When I visited the San Francisco Farm later on, I found another version of the acquisition of the same estate, this time as a written record. The text was in the lounge of the farm guesthouse, exhibited with other texts and photographs on the origins of the property. As already mentioned, the farm was established on land bought from the Bodoquena Farm, as narrated by Seu Joaquim. The San Francisco Farm website

\footnotetext{
7 Lienhardt, in his work on the African Dinka herdsmen, says, "Practically all of the extensive chromatic vocabulary of the Dinka is from cattle colors" (Lienhardt 1961: 37). The same could be said of the Nuer in the well-known study by Evans-Pritchard (Evans-Pritchard 1940).

8 The former Francesa Farm was visited by Lévi-Strauss in his passage through the Pantanal in the 1930s and is described in Tristes Tropiques (1955). Its purchase by Brazilian investors in the 1940 s was motivated by the nationalization movement promoted by the Vargas administration as described by Benevides and Leonzo (1999) in their study on the history of farms in the region.

9 The verb 'bagualhar' and the noun 'bagualhação' refer to a traditional Pantanal practice (no longer in use in many places), a kind of rustic handling of wild cattle, in which castration and slaughtering are performed in the field.
} 
says that "in 1973 the patriarch Laucídio Coelho (...) purchased 100.000 hectares of the former Bodoquena Farm and divided it up amongst his 12 children". ${ }^{10}$

The text to which I refer was a posthumous tribute to Mr. Laucídio Coelho, signed by Antonio Barbosa de Souza, a former administrator who worked with the patriarch of the Coelho family. It was a very detailed description of the negotiation of the Bodoquena estate, which portrayed Mr. Laucídio's personality based on his business attitude, not bowing before the "representatives of big international capital" with whom he was dealing. The Bodoquena Farm, as reported by the author of the text, was "a company controlled by Walter Moreira Salles (51\%), David Rockefeller (25\%) and Mr. Anderson of the US company Atlantic (25\%)." The wisdom of the patriarch, as evidenced by the following passage, was to negotiate on his own terms, refusing the partnership proposal and making a bid. Mr. Laucídio Coelho says:

- These gentlemen of national and international renown are powerful bankers, but clearly they are not farmers. They are not managing their farms successfully.

The final lesson, presented in dialogue form, can be seen as a lesson about bagual cattle, and involves the occupation of land by tame herds:

- Mr. Laucídio, can we buy this cattle? I believe they'll give us a good price. They should sell very cheaply.

- Antonio, I wouldn't want it for free! No way. If you take these cattle and mix them with another, the tame ones will follow them and will get feral, too. They'll be wild forever. This is poison. Lock them up (in the corral) and ask them to come get them. You must eliminate any seeds of bagual cattle or else they'll turn the tame into bagual. (...)

- I learned the lesson: bagual cattle are no good.

The author learns this lesson from the farmer, who considered bagual a 'poison', because it would make the tame cattle wild and stray. The point that interests me in this case is the contrast between his account and Seu Joaquim's narrative (quoted above) about the same event. In the case of the farm manager's text, written from the land buyer's point of view, the tame cattle could become unmanageable in contact with bagual cattle. The concern of the farmer, in this case, is that the tame cattle would learn the bagual behavior. As a good Pantaneiro, he knows the behaviors and movements are transmitted amongst animals in the herd, and he believes that merging the two herds would make the cattle feral.

In the case of Seu Joaquim's narrative, in turn, the wisdom of the cowboys lies exactly in the opposite direction: they seek to tame the bagual cattle by bringing them into the tame herd. They understand the intersubjective communication of the cattle, but believe that the merging of herds will result in a process of taming. In contact with the tame cattle, the herd would no longer be feral. Both narratives seem to share a common point of view: based on practical experience with cattle, there is an understanding of cattle communication amongst themselves and of what they do with their bodies and movements. They know the tendency of the herd to act as a group following behavioral patterns and agree that bovine behavior results from the herd interaction, but they disagree on the direction of the process: becoming tame or becoming feral are both possible outcomes of the relationship.

In a study carried out in the region of Poconé, north of the Pantanal, Campos Filho refers to the term "visonho" to designate cattle "who never saw people," and therefore would be tamer than bagual:

These cattle [bagual] are 'afraid of people' because they were 'escarreado', 'bagualhado', pursued to be caught. The 'baguás' run greater distances than the 'visonhos' and they do not hide, because they mistrust the riders greatly. (Campos Filho 2002: 137) 
In this case, it is important to note that the human actions of pursuing and frightening produce the bagual, term used here as one of the possible meanings of wild, in the sense of indomitable, feral. The "visonho" in turn, is tamer exactly because it never had contact with humans, because it lives in isolated areas that are wilder, here in the sense of that which is remote, secluded and inaccessible. Contrarily to what one might suppose using the domestic-wild distinction in a merely classificatory sense (when we say that the cow is a domestic animal and the jaguar a wild one), bagual cattle is not defined by belonging to a certain order, but by a condition or state. Tameness and ferality are not states of being; they are rather relational products of interactions between different cattle and humans. In the Pantanal, taming (which is not the same as domesticating) is a process in permanent tension with the animal's movement towards becoming bagual.

II

The Santo Antônio Farm covered an area of ten thousand hectares, fairly small by regional standards. At the time of my research, it was a rural community inhabited by thirty-four people, with a herd of around five thousand head of cattle. ${ }^{11}$ Only six cowboys - including the foreman - managed all the cattle. There was also the farm manager and an administrative assistant, who were responsible for the accounting, record keeping and dealing with suppliers and buyers. The farm owner was a construction entrepreneur from São Paulo. The office, located at the headquarters, was the administrative hub that centralized all information pertaining to the property. As is common in such a context, the main means of communication on the farmand the news channel for the residents and their neighbors was the radio.

Seu Joaquim was married to Dona Antônia, and they both lived in the main house in the only retiro on the property. The retiro was made up of three houses next to each other. In the center was the foreman's house; one of its rooms was used as a 'cafeteria', and Dona Antônia was responsible for the meals - breakfast, lunch and dinner - served daily to the cowboys and other farm employees, as well as to the biologists working on the research project on the Pantanal jaguar and other visitors. A second house nearby, smaller, was inhabited by a farm employee and his family. A third house (where I stayed during my field work), a kind of dormitory or "alojamento", was further from the other two across a flood plain and housed the employees whose families didn't live on the farm.

On one of the days that I accompanied the cowboys at work, we left on horseback before sunset towards a cattle paddock in order to take care of the calves. After about a half hour one of the cowboys slowed down, came to a halt and without getting off his horse, carefully examined the path around him. He identified the fresh trail, or "batida" as they call it, of a jaguar. As they looked for the calves a little later, he commented with his mates jokingly: "If the cat didn't eat them..."

The day's work consisted of gathering cattle that were spread around one of the invernadas and bringing them into a large enclosure, or picket. Once in the enclosure, the five cowboys doing the job would split up. Two of them would stay on horseback to capture the animals with the rope, while the other three waited in a corner of the enclosure with the medications and tools for treating them. When a calf was brought always followed by an apprehensive cow-, one of the cowboys would walk up to it and turn it on its back on the ground, using his hands and knee to restrain the calf, while his workmate tied its four legs. Then the ear was tattooed and pierced with an earring that had the same number as the tattoo. Throughout the process they medicated, vaccinated, and treated wounds and maggots; in the end, the calf was lifted by its legs and weighed with manual scales. The employee recorded all the information in his field notebook.

11 The human/bovine ratio (34:500o) gives us a notion of the respective populations (of humans and bovines) that live in the rural areas of this region of the Brazilian Midwest. 
I realized that much of the cowboys' job was to watch over the cattle and follow them in the field from a distance. This visual relationship was reciprocal and marked by continuous, repetitive movement and spatial distance. Through sound and visual contact, the cattle identified and observed the cowboys' movements - a horse racing suddenly, the rope turning above their heads, these were the cues for the cattle to move. The cowboys, on the other hand, watched the herd from afar on horseback, assessing the health of the animals. Only when additional identification was needed, or when they were going to care for or mark the animals, this surveillance at a distance was interrupted by sudden movements. When captured, that is, when the animal was subdued, the visual relationship was replaced by physical interaction and handling.

At times during my stay on the farm I could observe work within the corral, which was divided into parts: The funnel chute is like a funnel that leads to a narrow wooden corridor called chute, through which the cattle pass, one at a time. At the entrance and exit of the corridor, a cowboy controlled sliding gates. After the second gate, the neat to be weighed was held by the neck yoke - a wooden structure that closes around the neck to hold the animal on the scales. At the end of it all there's the crush, a small enclosed space with five gates controlled through levers by a person above. When passing through the crush, the animals are called out loud by a cowboy: "cow", "weaning calf", "weaning heifer", "suckling calf”, "suckling heifer". Each category is led to a different corral. The weaned calves were the ones to be sold by the farm. The heifers would stay on the farm to breed; the steers would be sold to slaughterhouses and butchers in cities such as Corumbá and Campo Grande. The average price was 600 reais per head at the time of the research.

Santo Antônio Farm worked with the breeding and raising of steers. During flood season part of the herd would be brought to the dry pastures of another farm, on the highlands of Pantanal, for fattening. The herd control and management system was rigorous and production had been growing over the years, as reported by Seu Joaquim. Talking about the farm production and beef supply for internal consumption, he told me the goal is for a cow to have one calf a year: "if the cow doesn't produce for too long, it gets in line for slaughtering". It is routine practice in Pantanal farms periodically to slaughter these cows, called "matulas", for consumption by the residents; the cost, below market price, is taken out of their paychecks at the end of the month.

The person responsible for slaughtering and butchering on the Santo Antônio Farm was the foreman himself. Two cows were slaughtered per month: one for the "married" employees (those living with their families in one of the farm houses) and another for the cafeteria, where the "bachelors" lived in the shed) had their lunch. As a rule, the canteen served beef in all three daily meals, including breakfast (traditionally, carreteiro rice), lunch and dinner (where meat is served stewed or roasted, usually accompanied by rice, beans and cassava). Fish such as the spotted sorubim and pacu were also appreciated, but were not served at the cafeteria during the times when I was on the farm except once during Lent season, when the local custom is to avoid red meat.

The slaughtering was carried out on a cement disk in the headquarters area, close to the foreman's house. It was part of farm life, and the mood amongst the cowboys taking part in the butchering was relaxed. They would talk loudly and laugh while working, making remarks about the size of the cow and the beef cuts that each would take home ${ }^{13}$. When they were done, several carrion birds like caracaras and vultures were already waiting for the leftovers. Next to where the slaughtering took place there was a small room into which the hide was brought to be salted and then hung on a fence to dry in the sun. Meanwhile the meat was cut into large chunks and hung on hooks in the butcher's shop located in a house next to the cafeteria, where it would be shared amongst the residents.

12 Many of them were married and had a family in the nearby cities of Corumbá or Miranda.

13 Banducci (1996) characterizes the designation of matula and the joking or even aggressive treatment dispensed to the cow in Pantanal farms as a process of distancing from the animal selected for slaughtering. 
Classic anthropological studies on animal categories and feeding relationships in western societies, such as the one by Edmund Leach (Leach 1964) and Marshall Sahlins (Sahlins 1976), show how the designations of animals are based on their participation as subjects or objects in human society. Sahlins describes how the North American default meal model is firmly based on the centrality of beef, often seen as a symbol of health and social prestige. Urban western society operates a radical symbolic decoupling in this case, between a food product and its animal origin; the concealment of the organic nature of meat takes place via verbal devices, evidenced by the distinction in the English language between meat as food and flesh as a part of the body (Sahlins 1976).

In the rural environment, on the other hand, there is an engagement of the cowboy with the animal that will be eaten while it's alive, and the passage from flesh to meat is part of the daily experience of the Pantanal cowboys. They admire the animal in the rodeos and rope challenges, value the speed and agility of the calf, and later enjoy salting its meat ${ }^{14}$. From the cow, almost everything is used as raw material for manufacturing utensils and working tools. An adequately shaped horn is used to make the guampa, container from which one drinks tereré - iced mate tea around which the cowboys gather to quench their thirst. After being stretched in the open air, cleaned and salted, the hide is tanned with the bark of a local tree, the angico (Anadenthera macrocarpa). It can then be used to make whips, knife sheaths, reins, saddle flaps (that help stabilize the saddle) the gun holster, the haversack (where they carry food), arreadores (used to produce a loud crack and make the herd move) and, of course, shoes, boots, hats and other clothing accessories.

The cowboys, who would wait for their turn to be able to use it, would dispute the hide of a slaughtered animal. The noblest and most valued tool is the rope: "The rope is the cowboy's weapon," they'd tell me. On a Sunday, the day off on the Santo Antônio Farm, I watched Laurindo's craftsmanship as he made a new rope for himself. Each cowboy is responsible for his tools, including the rope and the whole equipment the riding gear. Laurindo used four thin strips of leather, each measuring approximately sixty meters long - or thirty five braços (arms), the unit used on the farms - obtained through a spiral-shaped cut of the hide. Four balls were on the ground and the strips would be braided with the support of a wooden column on the shed porch. The cowboy would use his body weight to pull and tighten the braid; he explained that the movement would determine the final result. The tighter he pulled, the firmer the rope would be.

Cutting these strips - called tentos or small strings - is a task that requires great skill on the part of the cowboys. In the Pantanal, the reputation of a good craftsman, just like the reputation of a good roper, as reported by Banduccci (1996), can travel way beyond the farm where they work; other cowboys, farmers and acquaintances alike appreciate his services. In the control and handling of the herd, the cowboy's rope is literally what connects the cowboy-horse pair to the animal pursued. It is what allows the cowboy to subdue and control the strength of his animal adversary. It is with the rope that the calf is caught to be cared for; the loose cattle gathered back to the herd, the wild horse tamed and the bagual cattle captured. It is also with the rope that the matula cow is conducted to its sacrifice.

14 This makes me think about John Berger's essay Why look at animals?, when he writes: "A peasant becomes fond of his pig and is glad to salt away its pork. What is significant, and is so difficult for the urban stranger to understand, is that both statements are connected by an and and not by a but." (2009:16) 
Traditional cattle raising in the Pantanal, practiced on large flood plains, is recognized as having a relatively low environmental impact, since it has always preserved native vegetation and biodiversity (Campos Filho 2002, Mazza et al. 1994). Hunting tends to be very restricted in the Pantanal, as we will discuss later. In the last fifty or sixty years, however, there has been a change in local cattle raising with technicization, a drop in profitability of Pantaneiro cattle and their gradual substitution by other breeds.

A study by Embrapa-Pantanal ${ }^{15}$ describes the formation of Pantaneiro cattle showing how they have emerged from a slow adaptive process:

Through the process of evolutionary adaptation and the effects of natural selection on the bovines of Iberian origin, which bred for generations in the ecological conditions of the Pantanal, a local kind arose (Mazza et al.1994: 34).

According to the authors, the substitution of Iberian cattle by Zebu cattle of Indian origin (white cattle) was based on market criteria and led to an accelerated process of extinction of Pantaneiro cattle. They show how the appearance of the local ethnospecies took place after bagual cattle had become dispersed through the Pantanal region during the colonization of the Paraguay River basin, after the 18th century. ${ }^{16}$ The threat of extinction of the Pantaneiro bovines is related to the substitution of traditional cattle-raising by models from "outside" the region, based on market rules and intensive management (1994: 35-38).

From a similar perspective, Campos Filho points to the ambivalences of local cattle raising practices in relation to the different kinds of cattle:

The 'baguâ' is also a symbol of economic backwardness, given its 'wild' condition in comparison with manageable, 'tame' animals. That's why many farmers deny having them, hiding the fact. At the same time they value the 'baguá' as a symbol of the Pantaneiro (Campos Filho 2002: 139). ${ }^{17}$

The author defines the existence of Pantaneiro cattle based on a relationship with the environment that extrapolates human control when he states that:

Regarded as natives, the bovines don't need humans to survive as a species in the Pantanal. The only category really created by humans is the 'ox', the emasculated male resulting from castration (2002: 140).

Castration would be, therefore, not only a handling action, but also that which marks the passage from nature to culture. The idea of any bovine as a domestic animal introduced by human action is, according to the author, an idea that is foreign to the Pantaneiro lifestyle. To characterize this perception of bovines as a native species, Campos Filho says it is a process of "naturalizing through culture" (2002: 141).

Álvaro Banducci, who worked in the Nhecolândia Pantanal, states that:

On the farm where there is bagual cattle the cowboy sees himself as "authentic", because he must get up early, go many hours without food and run greater risks in the field, while he sees the other as a lazy cowboy, weakened by the "ease" of his work (Banducci 1996: 134).

15 Embrapa-Pantanal is the most important governmental research institution in the region and is currently developing some projects for the conservation of the Tucura (Mazza et al. 1994).

16 The Guaicurus and Paiaguás are indigenous groups famous for being excellent riders and stealing cattle from the herds that cross their territories, offering resistance to the colonization of Southern Pantanal.

17 The author chooses to spell "baguá", according to the regional pronunciation. In recordings and oral records collected during my own research, the same pronunciation was confirmed, but I chose to use "bagual" for this paper, according to the spelling used in other bibliographic sources (Benevides e Leonzo 1999; Mazza et al 1994, Banducci 1996). 
The identity of the pantaneiro is defined by the difficulties and challenges faced and refers to a kind of transference that confers prestige and value to the cowboy based on the animal he is able to subdue or tame. For the author, it's an identity constructed through a permanent battle with the dimension of the wild, with an otherness that needs to be organized, controlled, tamed daily on the farms.

In the case of bagualhação, as the capturing of bagual cattle is called, the handling principles are simplified to a minimum: castration, marking and slaughter. Referring to this practice, Banducci reports that "the first mark the cowboy imprints on cattle is a cut in the ear, often performed in the field". He adds that "an animal without this indication of handling and property is also called 'oreia' (ear), considered a wild, bagual animal" (Banducci 1996: 110-113).

The procedure can be compared to another traditional activity in the Pantanal farms, monteiro pig hunting. The monteiro pig is the domestic pig that, as the locals say, "stretches into the woods" and becomes wild. The term "stretch", applied to some feral pigs, corresponds to a transition phase, since only after a few generations in the wild state do the pigs acquire morphological traits as the grey fur and pronounced fangs that characterize the monteiro. In relation to these, Banducci comments that:

[The] ideal specimen for human consumption is the male, previously castrated in the field to fatten up and lose the characteristic smell - "miscazinha", as they refer to the odor common to game meat. (1996: 111)

When captured for castration, the pig is marked with a cut in the ear or tail, which helps identify the castrated male that is adequate for consumption. The uncastrated monteiro pig, called guaiaca, is the equivalent of a bull, also inadequate for human consumption. The capturing of a monteiro pig, a traditional hunting activity, is similar to the bagualhação of cattle. Both are based on a series of elements used by the cowboys to classify and identify the animals. In this case, handling is simplified to a minimum, translated into a binary code: marked or non-marked, castrated (adequate) or uncastrated (inadequate). Both activities are situated between hunting and herding, involving procedures of tracking, pursuing and capture typical of hunting and, at the same time, handling procedures such as marking and selecting certain classes of animals for consumption.

\section{IV}

In a study on the traditional Pantaneiro hunting model, Lourival and Fonseca considers it an environmentally sustainable practice (Lourival \& Fonseca 1998). The main reason for this conclusion is that the hunting practices in question have the monteiro pig - an exotic species (the domestic pig turned wild and adapted to the local environment) - as its main prey. The claim is that by replacing native species preferred by local hunters - especially wild pigs, collared peccaries (Tayassu tajacu) and white-lipped peccaries (Tayassu peccary) - the monteiro pig reduces the hunting pressure on these species (Idem). Regarding jaguars and pumas, on the other hand, considered "damaging" or "harmful" species by cattle farmers, the author believes the hunting pressure is of a different order. Historically, the development of firearms and the intensification of cattle management methods led to the elimination of jaguars in an increasingly systematic process, which led to the eradication of these species in some regions.

Traditionally in the Pantanal jaguar hunters were caboclos, bugres hired by landowners specifically for getting rid of jaguars ("desonçar") in certain areas intended for cattle raising, making them safe for human settlements and their herds ${ }^{18}$. The negative symbolism of predators to native populations living with them is frequently part of a process of criminalization and moral condemnation that accompanies

18 The theme was explored by Guimarães Rosa in one of his most brilliant short stories, Meu tio o Iauaretê, from 1961. 
the elimination or systematic control of these species. In the first half of the $20^{\text {th }}$ century, professional hunters and experienced local guides would organize a common kind of hunt in the history of Pantanal, the "safaris", when wealthy tourists from around the world would hunt for jaguars in the region. This kind of sport hunting is described in detail in autobiographical books by hunters like Sasha Siemel (Siemel 1953) and Tony Almeida (Almeida 1976). There is much evidence that points to the continuation of such practice in the Pantanal region. A notorious example was widely covered by Brazilian news media that reported on an illegal safari scheme that was investigated by Brazilian Federal Police in 2009, leading to arrests and seizure of weapons and sniffer dogs ${ }^{19}$.

Analyzing the current situation, the effectiveness of existing legislation and proposals for predator management in the country, specifically in the case of the jaguar, Silveira and other authors discuss the political aspect of conservation: "Licenses to eliminate harmful animals can only be given by a competent authority". However, "this authority has never been specified" and "there is no official authorization or government statistics on the management of predators in the country" (Silveira et al. 2008: 30).

The traditional practice of eliminating felines with the use of dogs was mentioned in interviews conducted on four farms, out of a total of ten visited during my research ${ }^{20}$. This type of hunting is often defended by local owners as a control measure needed to maintain their businesses. An example is the testimony of a landowner of a region near Corumbá, recorded in November 2008, transcribed as follows:

And what is the importance of the jaguar for the Pantaneiro? Does it have any cultural significance?

Speaking as a cattle raiser, I'd rather it didn't exist. But we know it's part of a food chain, that it predates other animals and therefore it's controlling. On its own controlling these animal populations. But nothing kills it, right? Only man kills it. Here's what I think: The way the legislation is, it prohibits but it doesn't really prohibit, because there is no enforcement. Take me, for example. My family has been in the region for fifty years. We've been controlling for fifty years. Because we are here in the Pantanal. We preserve the Pantanal. If you look at my farm, it's been like this for a long time; I mean, there are animals, there are cattle. And I need to make money from it. It's how I make a living, right? So, the only way for me is to eliminate the individuals that bring me financial losses. And I'll tell you: my land is full of jaguars. But they are not getting in my way. So, let them live there! They don't bother me. There is no problem whatsoever.

This example shows what appears to be a fairly recurrent attitude and also demonstrates the farmer's disregard for the public authorities in relation to this issue. Since the 1980s, studies focussing on the conservation of the Pantanal jaguars have shown that the region has preserved the environmental conditions and the prey base on which the species depends. In general, it is not the lack of natural prey that makes the jaguar attack cattle, but rather the availability of a new food resource, more easily accessible than the native prey species. In short, what many of these studies have pointed out is that over two centuries of cohabitation in the Pantanal, cattle became part of the natural diet of jaguars, often their main food item in terms of biomass (Crawshaw \& Quigley 1984, Azevedo \& Murray 2007, Cavalcanti et al. 2010).

The hunting legislation in Brazil has been regulated since 1967, when the hunting of any species of native wildlife was prohibited. The law was last modified in 1988, when more severe punishments for hunters were established. In practice, however, to this day there is no effective government policy for the management and conservation of wildlife, and many Pantanal landowners, as we have seen, continue to

19 An article on this case can be found on Ibama's website: http://www.ibama.gov.br/publicadas/ibama-ms-multa-cacadores-de-oncas-pegos-em-operacaoconjunta-com-a-pf Consulted on 28 November 2015

20 This might not be a statistically significant result for the regions studied, as I worked in areas of influence of conservation projects and tourism 
claim the right to kill animals that attack livestock. Experts point to selective hunting of the species as the main threat to the conservation of the Pantanal jaguar population at the present time (Silveira et al. 2008). Conservation projects deal with this conflict.

More than $95 \%$ of the Pantanal area is occupied by private properties, which are currently inhabited by over four million head of cattle²1, according to the IBGE (Brazilian Institute of Geography and Statistics). In addition, cattle raising is one of the main agribusiness development fronts in the country and farmers have a powerful political influence in the states of Mato Grosso and Mato Grosso do Sul. As a result of the complex framework of ecological and economic relations involving cattle and their predation by Pantanal jaguars, the strategies currently developed in the region by major international NGOs such as WCS (World Conservation Society) and the WWF (World Wildlife Fund) link the conservation of jaguars to the productive chain in cattle raising using endangered species to attract attention as a red flag.

The association between environmentalism and cattle raising involves a series of new concepts, such as " responsible consumption", "food security", "traceability" or "socio-environmental sustainability", and is articulated on the establishment of policies based on environmental indicators. In terms of finances, regional alliances, research areas, public representation, conflicts between stakeholders and ecological relationships, the associations between the jaguar and the Pantanal cattle seem to multiply endlessly. These associations expand from the farm and involve other agents in the productive chain of beef, including slaughterhouses, butchers, distributors, supermarket chains and large fast food chains around the world. This is the chain from which new elements appear, connected to conservationist movements, like beef certification, conscious consumers and endangered species.

The Pantanal jaguar is what has been called in Conservation Biology a "flagship species", or "keystone species" for the Pantanal. The first term refers to species that are considered "charismatic" and attract public attention; the second refers to the fact that the existence of large predators depends on the maintenance of the entire food chain from which they depend, meaning that their preservation implies the preservation of many other species (Silveira et al. 2008). Studies on the behavior of the Pantanal jaguar, as discussed above, showed that the cattle introduced by humans became the most abundant and common prey to jaguars. This subverts a paradigm and disrupts old conceptions of a well-defined boundary between the wild and the domestic environments, or between nature and culture.

The symbiotic relationship between the jaguar and cattle is useful to question the definition of the situation in terms of an ecological conflict between farmers and jaguars, in which a native wild species feeds on an exotic domestic species. The situation, when we take into account the plural aspects of the agencies involved, may not be reducible to final distinctions between human and non-human animals, wild and domestic species and conflicts resulting from the invasion of their respective environments. It is rather a situation in which jaguars, cattle and humans are inserted in complex processes that involve movements between states of ferality and domesticity. The intensive cattle management in the corral, during vaccination and animal counting, can be interpreted as an aspect of the productive relations in which the animal is treated as a thing, an object, undifferentiated head of cattle. The handling of animals in the field, on the other hand, is traversed by multiple relations with exceptional individuals who break fences and stray from the herd, with horses that are hard to break, with calves claimed by the jaguars, deaths caused by flooding, snakes and poisonous plants.

21 Having reached six million before the great flood of 1974, event that marks the beginning of a crisis in traditional Pantanal cattle raising (Campos Filho 2002). 
The expansion of new cattle raising practices in the Pantanal led to the gradual disappearance of bagual cattle and along with it a number of traditional customs. What disappears in this case are not only cattle, evidently, but also ways of life and unique experiences of the world that are not restricted to herd management practices. In the quote below, Campos Filho mentions a "bovine culture" to designate the ecological relations at stake in the Pantanal, thereby restricting the role of cattle neither to the production paradigm, nor to natural selection:

Each bovine group developed a history in its 'place', displaying unique behaviors of migration and use of land, environment and food during different 'seasons', called 'cattle game', passed on to younger animals, which allows us to talk about a 'bovine Pantanal culture' (Campos Filho 2002: 126)

The "game" here is both a "use of environments" by the cattle and what cowboys learn to recognize in order to play. Cattle are understood in this case as agents, and not just as a raw material or objects in human culture. The idea of culture, when seen specifically as a project or as a production of a human environment - artificial, symbolic, technological - implies the existence of a raw material, an inert natural substrate and a corresponding instrumental and objective concept of animality. The alternative idea of a "bovine culture" points in the opposite direction to the realization that cattle build and reproduce the Pantanal environment, producing it as it is: inhabited by wildlife, by the herds themselves and by the cowboys.

As we have seen, cattle raising as practiced traditionally has the reputation of having preserved wildlife and regional biodiversity to a large extent. Currently the major threats to the Pantanal environment come from the transformations resulting from technified and intensive agribusiness and by a developmentalist logic. The conservation of Pantanal cattle, or tucura, inscribes itself here, against the grain of this movement. Currently considered an endangered ethnospecies, this type of cattle associates the preservation of traditions and the conservation of local ecosystems.

For many Pantaneiros, the absence of cattle in a particular area seems to signify a process of decharacterization of the landscape, where the field becomes "dirty", a category that refers to the closed and impenetrable bush and differentiates itself both from "clean" (the open fields of pasture) and from capões and mountain ranges (forested areas) ${ }^{22}$. The continuously grazing herds "clean" the field and open tracks through which the cowboys circulate. The action of cattle is understood in this case as a force that produces and maintains the landscape as it is known and valued by the Pantaneiros.

Finally, I would like to resume the story with which I started this article. In it, a woman (the greatgrandmother of the narrator cowboy) is overcome by an animal becoming when she gets lost in the woods and goes to live with bagual cattle. Afterwards there is a return to a normal state through a taming linked to religiousness. But this movement of return is not completed: one month after she is captured, the young lady $\operatorname{dies}^{23}$. What is at stake in the story is a movement that crosses the boundary between humans and animals. The bagual condition is formulated in this case as the threshold, not only between a state of tameness or domestication of non-human animals, but also of the very condition of humanity. The human condition may be understood in this sense, as a domesticated, or at least tamed, condition.

\footnotetext{
22 The contrast between clean and dirty suggests the famous study by Mary Douglas, Purity and Danger (1966) on the association between cultural taboos (especially related to food) and the classificatory and linguistic aspects of the idea of pollution, connected to some form of deviation from normative categories used to define the natural world.

23 Just as in some examples quoted by Deleuze and Guattari (1997) on their concept of animal becoming, here there is a movement of deterritorialization of the human and the agency of a demonic alliance that drags the story's character to an early death.
} 
The opposition between feral (bagual) and tame, as in many other parts of rural Brazil, seems to make more sense in the case of Pantanal than that between wild and domestic. Bagual is a becoming and not a belonging to a class. Far from the linearity of predictable and deterministic behaviors attributed to cattle herds and human beings when we accept the notion of a domesticated animal, here we find the dynamic and unpredictable elements of the Pantanal relationships. Breaking and taming, on the one hand, and becoming wild or bagual, on the other, are open possibilities of a unique symbiotic experience of a community that includes human and non-human animals.

Translated by Flavio Ribeiro

Received, February 27, 2016, Approved, October 20, 2016

\section{References}

ADÁMOLI, J. 1982. "O Pantanal e suas relações fitogeográficas com os cerrados: discussão sobre o conceito de complexo do Pantanal”. Anais do $32^{\circ}$ Congresso nacional da Sociedade Botânica do Brasil. Teresina-PI, Brasil. pp.109-119.

AGAMBEN, Giorgio. 2002. The open - man and animal. California: Stanford University Press.

ALMEIDA, Antonio de. 1976. Jaguar hunting in Mato Grosso. England: Stanwill Press.

ALMEIDA, M. W. B. de. 2013. “Caipora e outros conflitos ontológicos”. R@U: Revista de Antropologia da UFSCar, 5(1):7-28.

AZEVEDO, Fernando Cesar Cascelli; MURRAY, Dennis L. 2007. "Evaluation of potencial factors predisposing livestock to predation by jaguars". The Journal of Wildlife Management, 71(7): 2379-86.

BANDUCCI JR., Álvaro. 1996. Sociedade e natureza no pensamento pantaneiro: representação de mundo e 0 sobrenatural entre os peões das fazendas de gado na "Nhecolândia" (Corumbá/MS). Dissertation in Social Anthropology. Programa de Pós-Graduação em Antropologia Social, USP.

BENEVIDES, Cezar \& LEONZO, Nanci. 1999. Miranda estância. Ingleses, peões e caçadores no Pantanal matogrossense. Rio de Janeiro: FGV Editora.

BERGER, John. 2009. Why look at animals? London: Penguin Books.

CAMPOS FILHO, Luiz Vicente da Silva. 2002. Tradição e ruptura. Cultura e ambiente pantaneiros. Cuiabá: Entrelinhas.

CAVALCANTI, Sandra M. C.; MARCHINI, Silvio; ZIMMERMANN, Alexandra; GESE, Eric M.; and MACDONALD, David W. 2010. "Jaguars, livestock, and people in Brazil: realities and perceptions behind the conflict”. USDA National Wildlife Research Center-Staff Publications. Paper 918. University of Nebraska. http://digitalcommons.unl.edu/icwdm_usdanwrc/918. Consulted on 25 March 2015.

CRAWSHAW, Peter G.; QUIGLEY, Howard B. 1984. "A ecologia do jaguar ou onça pintada (panthera onca palustris) no Pantanal matogrossense”. Estudos bioecológicos do Pantanal matogrossense - relatório final - parte I. Brasília: Instituto Brasileiro de Desenvolvimento Florestal - IBDF. Mimeo.

DELEUZE, Gilles \& GUATTARI, Felix. 1997 . “Devir-intenso, devir-animal, devir-imperceptível...”. In: Mil platôs - Vol. 4. São Paulo: Editora 3. pp. 11-115.

DESCOLA, Phillipe. 1998. "Estrutura ou sentimento: a relação com o animal na Amazônia". Mana, 4(1): 23-45.

DESCOLA, Phillipe; PÁLSSON, Gísli (orgs). 1996. Nature and society. Anthropological perspectives. Londres: Routledge

DOUGLAS, Mary. 1966. Purity and danger: an analysis of concepts of pollution and taboo. London: Routledge and Keegan Paul 
ELLEN, Roy; FUKUI, Katsuyoshi (org.). 1996. Redefining nature. Ecology, culture and domestication. Washington, D.C.: BERG.

EVANS-PRITCHARD. 1940. The Nuer: a description of the modes of livelihood and political institutions of a Nilotic people. Oxford: Clarendon Press

KNIGHT, John (org.). 200o. Natural enemies: people-wildlife conflicts in anthropological perspective. London: Routledge.

HARAWAY, D. 2003. The companion species manifesto: dogs, people, and significant otherness. Chicago: Prickly Paradigm Press.

INGOLD, Tim. 1995. "Humanidade e animalidade”. Revista Brasileira de Ciências Sociais, 10(28): 39-53 .

INGOLD, Tim. 1994. What is an animal? London: Routledge

LEACH, Edmund. 1964. "Anthropological aspects of language: animal categories and verbal insults". In: E.

H. Lenneberg (ed.), New directions in the study of language. Cambridge, Mass.: MITPress. pp. 23-63.

LÉVI-STRAUSS, Claude. 1962. La pensée sauvage. Paris: Plon

.1955. Tristes tropiques. Paris: Plon

LIENHARDT, G. 1961. Divinity and experience: the religion of the Dinka. Oxford: Clarendon Press.

LOURIVAL, R. F. F. \& da FONSECA, G. A. B. 1998. "Analise de sustentabilidade do modelo de caça tradicional, no Pantanal da Nhecolândia, Corumbá, Ms”. In: R. E. Bodmer and C. Valladares-Padua (eds.), Manejo de fauna na América Latina.. Brasilia: Instituto Mamirauá. pp. 123-172.

MAZZA, Maria Cristina Medeiros; MAZZA, Carlos Alberto da Silva; SERENO, José Robson Bezerra; SANTOS, Sandra Aparecida; PELLEGRIN, Aiesca Oliveira. 1994. Etnobiologia e conservação do bovino pantaneiro. Corumbá: CPAP/ EMBRAPA.

PEREIRA DA CUNHA, Comandante H. 1922. Viagens e caçadas em Mato Grosso. Rio de Janeiro: Livraria Francisco Alves.

ROSA, João Guimarães. 1985 [1961]. "Meu tio o iauaretê". In: Estas estórias. Rio de Janeiro: Ed. Nova Fronteira. pp. 160-199.

SAHLINS, Marshall. 1976. Culture and practical reason. Chicago: University of Chicago Press.

SCHALLER, George B. 2011. "Politics is killing the big cats". National Geographic Magazine, Dec 2011.

http:/|ngm.nationalgeographic.com/2011/12/tigers/schaller-text. Consulted on February 2015.

SCHALLER, George B. 2007. A naturalist and other beasts: tales from a life in the field. San Francisco: Sierra Club Books.

SIEMEL, Sasha. 1953. Tigrero! New York: Ace Books.

SILVEIRA, Leandro; BOULHOSA, Ricardo; ASTETE, Samuel; JÁCOMO, Anah Tereza de Almeida. 2008.

"Management of domestic livestock predation by jaguars in Brazil". In: Cat news - The jaguar in Brazil -

Special issue n. 4. Switzerland: IUCN/ Cat Specialist Group. pp. 26-30.

SÜSSEKIND, Felipe. 2010. O rastro da onça: etnografia de um projeto de conservação em fazendas de gado

do Pantanal. PhD thesis, Programa de Pós Graduação em Antropologia Social, Museu Nacional,

Universidade Federal do Rio de Janeiro.

. 2012. "A onça-pintada e o gado branco". Anuário Antropológico, II: 111-134.

. 2014. O rastro da onça: relações entre humanos e animais no Pantanal. Rio de Janeiro: 7 Letras.

UEXKÜLL, J. von. 2010 [1934]. A foray into the worlds of animals and humans. Minneapolis: University of

Minnesota Press.

\section{Felipe Süssekind}

Department of Social Sciences, Pontifícia Universidade Católica do Rio de Janeiro,

Rio de Janeiro/RJ, Brazil.

E-mail: felipesussekind@gmail.com 